\title{
Experiencing Highgate Cemetery as a Place Landscape, Text, Threshold
}

\section{Carla Danani}

\section{Approaching Highgate}

Human beings are always involved in space-time games. ${ }^{1}$ They are not in the world in the way things are, because the relationships they have with space and time are intrinsic to their existence and constitute them. ${ }^{2}$ As Maurice Merleau-Ponty says, «I belong to them [space and time], my body combines with them, and includes them.» ${ }^{3}$ For human beings, living is tantamount to perceiving, acting, knowing, feeling and moving by means of a certain hold on space and time which allows them to locate and orientate themselves. They live in and live on places, with other human and non-human beings. Human experiences are always social-spatial-temporal experiences. The logic of existence is therefore always a topology.

For my research, this means that there is always a «here» from where we are asking about Highgate Cemetery and in which we are talking about it. This is both a limit for our understanding and its condition of possibility, giving us words, narrations and questions only through which and from which thoughts can develop. Knowledge is always knowledge of something, and there are many ways to grasp something through thinking: in any case, we can say that we are always thinking of something from and in somewhere. An act of knowing «lives on» this particular something with which it is dealing, generally speaking just as our existence is also «living on» the world. Therefore, investigations must always be characterized by an ethical concern towards these relations and also towards all those links arising from people in their interactions among each other.

Knowledge is a kind of experience and ethics is implied in our search for truth. What are we thinking about when we say «Highgate cemetery»? Whatever we are referring to, the question is where? This means that the question is about a place. First of all, dealing with Highgate Cemetery

1 See Heidegger 2002.

2 See Danani 2014; Danani 2017a.

3 Merleau-Ponty 1962, 162. 
means to deal with the experience of a place, a meaningful space. ${ }^{4}$ But places are not mere things or objects. Human beings, who can ask about places, have a special relationship with them, for places have physical, social and cultural dimensions. In different ways, they play specific roles in human life and change over time. One can better say that places happen, rather than that places are. ${ }^{5}$

How can we understand places and place experiences? I propose here a hermeneutic-phenomenological approach. It is fruitful in highlighting the many aspects of places, because it considers the different ways in which things appear in the experiences we have of them: their coming to consciousness, their ways of giving themselves in a series of perceptual processes, their arising from the horizon of the world in which we are involved. ${ }^{6}$ Husserl called intentionality the directedness of experience towards something in the world, involving temporality (the stream of consciousness), spatial awareness, attention (distinguishing focal and marginal or «horizontal» awareness), self-consciousness, empathy, intersubjectivity and linguistic activity. Phenomenology points out many subjective, practical and social conditions for the possibility of experience, highlighting embodiment, bodily skills, cultural context, language and other social practices and contextual aspects of intentional activities. Localization (Edmund Husserl says Lokalität) is a relevant coordinate in one's perceptual field, independent of the localized perceptual contents and enabling human beings to speak about places. ${ }^{7}$ By answering the question where?, Highgate

4 The style of Highgate Cemetery is neo-gothic, it is not just an accurate reproduction of the architecture of the medieval gothic era, but an interpretation especially focused on the decorations of the buildings aimed at recreating the atmosphere typical of the medieval world. See Chandler 1971, 4. In the 19th century the neogothic style became an element of tradition and continuity, as well as source of national pride for the English people.

5 See Casey 1996; Danani 2018, 96-97.

6 See Husserl 1994, 268: «Die Weltvorstellung ist nicht eine Vorstellung unter meinen Vorstellungen. Es ist eine universale Bewegung und Synthese in der Bewegung aller meiner Vorstellungen, derart, daß all ihr Vorgestelltes zusammengeht zur Einheit einer Welt als einander geltender, das Korrelat der immerzu werdend gewordenen Einheit aller meiner Vorstellungen - Vorstellungen, die ich habe, hatte und haben werde.» Translation by the author: «The world-representation is not a representation among my representations. It is a universal motion and synthesis in the motion of all my representations, in such a way that all that they represent comes together in the unity of a world that counts for each other, the correlate of the continually developing and developed unity of all my representations - the representations that I have, I had and I will have.»

7 See Husserl, 2001. 
Cemetery is experienced as a place and as a complex of localized contents. These contents are "given» and we can find general regularities that are directly graspable in the configuration of what is given. ${ }^{8}$ Giovanni Piana says that «the authentic objective of description, are not by all means givens, but rather rules; more precisely, rules determining the display of this or that perceptual formation, of this or that objectual formation in general. [...] And this goes hand in hand with the highlighting of nexuses and functional relations, of the modes of articulation, of reciprocal determinations.»9

Human beings, however, understand what is given to them only through words, concepts, images, languages and practices through which they find and build the world they dwell in: the structures of experience are interpretative ones.

Focusing on some experiences one can have of Highgate Cemetery, and trying to highlight what appears in them, one can start only with those tools which are in one's toolbox. They change, and meanings change with them, even if they always refer to something that is given in its articulation, and not simply created by them. This does not mean that «anything goes» because some meanings are inappropriate and are "dead ends» (sensi vietati). ${ }^{10}$ Even if people can use a meaning, they always have to highlight the structure of its elements and to respect its cultural, social, and historical context if the goal is to interpret it. ${ }^{11}$

The effort to grasp what is given within one's experience is endless. In any case, by experiencing Highgate Cemetery as a place and thinking in depth on its localized contents, I think that one can grasp their nexuses and functional relations, modes of articulation and reciprocal determinations by speaking of Highgate as a landscape, as a text and as a threshold.

\section{Highgate as a Landscape}

People tend to perceive «landscape» as nature modified by human beings during a lengthy period of history, ${ }^{12}$ the totality of the signs characterizing a more or less wide part of the earth's surface which distinguish it from

8 See Piana, 2016, 202.

9 Piana 2016, 201.

10 Eco 2000, 54.

11 Eco 1990, 111.

12 See European Landscape Convention, Florence 2000: «Landscape means an area, as perceived by people, whose character is the result of the action and interaction of natural and/or human factors» (art. 1); «landscape...as an essential component of 
other parts. These signs are marks of natural forces (natural landscape) and human work (cultural landscape). A landscape takes on the trends and characteristics of the social groups that shaped it; it is a living and changing reality which involves naturalistic, cultural, aesthetical and ethical aspects. Highgate Cemetery «gives» itself as a landscape manifesting itself as a part of a territory, of a hill that nowadays is a district in London.

A landscape is not an environment. A landscape is its form, ${ }^{13}$ in which there is a simultaneous presence of past and present (it has a double contemporaneity). ${ }^{14}$ Human beings live surrounded by their environment, which contains the conditions for life and reproduction of life, such as specific weather, climate, soil and all the physicochemical and biological characteristics useful for life. We can speak of a social and economic environment, too. Compared to it, a landscape is rather its specific and perceivable unity, the unique complexity of its structures and relations, ${ }^{15}$ of the morphological features which have their historical origins in climatic and generally natural aspects, but also in social relations, legal institutions and technologies.

Highgate Cemetery is a sepulchral landscape, because it is a place where the dead are buried and its form is shaped by many graves and tomb ornaments. Human beings do not build cemeteries in every time period. Even when they buried the dead, they did not always do so in graves and not always in a group of graves. We do not speak about a cemetery when we have only one grave. It appears in our experience as an organized group of graves with its specific form and frame. The etymology of the word «cemetery» comes from the Latin coemeterium, which in turn derives from the Greek koimétêrion, which means place of «rest», «dormitory». This name was originally given to the portico for pilgrims. It is only with the spread of Christianity that "cemetery» takes on the value of necropolis and burial ground: «The Church, which embraced believers when they were alive, becomes the guardian of their sleeping remains. Hence the cemetery - neologism invented by Christians - as a possibility for everyone to have a common dormitory in the light of the common awakening. And whereas pagans preferred to call it necropolis [which means «the city of the dead»],

people's surroundings, an expression of the diversity of their shared cultural and natural heritage, and a foundation of their identity» (art. 5).

13 Venturi Ferriolo 2003, 143 referring to Rosario Assunto's distinctions between territory, environment, and landscape (see Assunto 1976, 45-48).

14 Venturi Ferriolo 2003, 149 (referring to Lorca 1993, 132).

15 Venturi Ferriolo 2003, 132. 
Christians have always considered it the place of the sleep waiting for the resurrection.» ${ }^{16}$

Many monumental architectural works of the past exhibit cemeteries and tombs as something to glorify events and leaders and offer a specific representation of history. Many cemeteries were places where human beings disappeared into the framework of a civil and public death. In the modern world sepulchral landscapes become, perhaps, more «democratic», and it seems that a kind of immortality can concern everyone.

The way a sepulchral landscape is considered depends on the way death is considered. If death is something marginalized, then the cemetery becomes the archetype of all ghettos; if death is understood as a passage, it becomes a place which refers to the possibility of an afterlife. A city of the dead or a place for lasting sleep, in such a landscape death becomes prominent, and somehow takes on meaning.

Manufactured by the living and relying on the living, the elements of a cemetery express the relationship between human beings and death. This is not a mere biological fact, but a complex cultural event. These elements are functional but at the same time meaningful, and include many symbolic features. They shape an aesthetic and ethical form, as well: in the specific characteristics of this place one perceives its normativity for behaviour, because it is a rather extra-ordinary place.

Death is deemed to be a leveller of the hierarchies and differences that characterize everyday life and distinguish between people. Nevertheless, does a sepulchral landscape really tell us about equality between people? The rituals that mark times of life and death are social factors which build a community and by which a community recognizes itself as such. Often differences are rebuilt in a cemetery, and it becomes relevant who is buried there, more than the fact that a human being is buried there. The very importance of a grave can derive from the social role that an individual had in that society, rather than from their dignity as human beings. Therefore, we can say that cemeteries are mirrors of the communities of the living and are places that tell about the rules of inclusion and exclusion, about the social, cultural and religious divisions that are working in the city of the living. In this sense, they are more places of the living than of the dead.

On the one hand, death creates solidarity among people, but it does this by reminding them that it is an extremely and solely personal possibility, since nobody can die in the place of another person. This states a common

16 Di Molfetta 2006, 747. 
fate, but at the same time claims consideration for the singularity of each person, implying that we are different from each other.

Vitruvius said that architecture must last in time. This idea is stressed by the sepulchral landscape. In order to speak about Highgate Cemetery, we need to place it in the specific time when it was founded, but this historical time informs us about only a few aspects. Spatial forms have the power to make visible what the past leaves behind. ${ }^{17}$ Architecture and spatial configurations are sets of temporal relations: they allow us to perceive and experience the many links that cannot be reduced to any present. ${ }^{18}$

If every place holds time in space, more than most other places, a cemetery has the vocation to last over generations. ${ }^{19}$ It is a landscape telling us that all is not finished, whether it be on earth or even in the «netherworld». In this sense one can say that a cemetery uses death against death. Whilst 40 years after individuals die there will be few people who were personally acquainted with them alive to remember them, a cemetery will continue to be a legible story about them, as long as stones, columns or statues survive. We can ask about the «truth» of this story, observing that every kind of memorial is a specific portrayal of the deceased by those who survive - the dead do not bury themselves. ${ }^{20}$ In these ways cemeteries tell us more about life than death.

In Highgate Cemetery the long-rotation plants, the evergreen trees resisting seasons and years refer to persistence (fig. 1), whilst the short-rotation vegetation creates an atmosphere expressing the idea of life renewing (fig. 2). The return to ancient Egypt and the use of geometric forms tell of the possibility of abiding over time. The tombs paradoxically refer to death by representing immortality. One can read it in many images of angels but also in many columns or statues that must remain forever.

17 See Ferrari 2007, 44.

18 Deleuze 1986, 270 (Deleuze talks about images).

19 See Schlögel 2003.

20 See Parker Pearson 1999. 

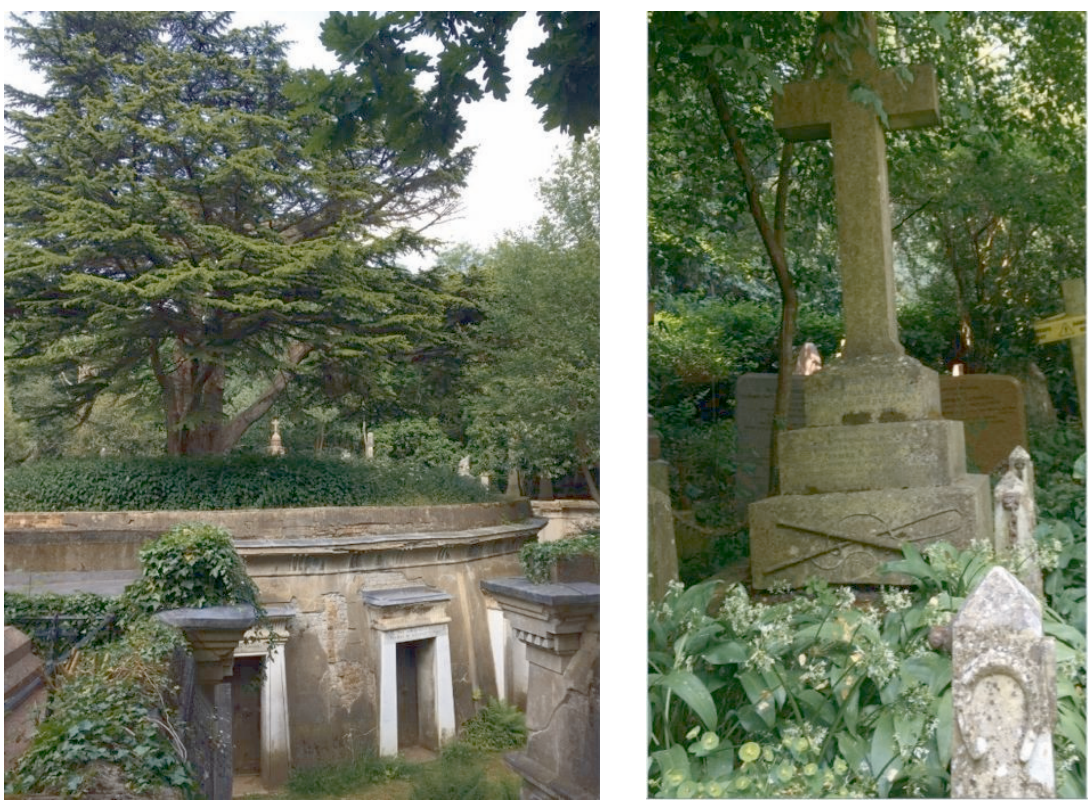

Fig. 1: Long-rotation evergreen, Cedar of Lebanon (Image: Carla Danani 2017).

Fig. 2: Short-rotation vegetation (Image: Carla Danani 2017).

Like every landscape, Highgate can be experienced in different ways: a haptic perception ${ }^{21}$ is different from an optic look, for example. We call optic a kind of look arising from an external point of view, but able to catch the overall frame of a place. We call haptic a kind of complex perception in which sensory, motion and cognitive systems all work together; it focuses on things giving the observer tactile, immersive effects. ${ }^{22}$ Haptic percep-

21 Deleuze/Guattari 1987, 493: they quote Alois Riegl, along with Wilhelm Worringer and Henri Maldiney, as the artists who gave fundamental aesthetic status to the relation between close range vision and haptic spaces.

22 Gibson defined the haptic system as «The sensibility of the individual to the world adjacent to his body by use of his body». Gibson and others emphasized the close link between haptic perception and body movement: haptic perception is active exploration. See Gibson 1966. See also Pallasmaa 1994, 35: «We behold, touch, listen and measure the world with our entire bodily existence and the experiential world is organized and articulated around the center of the body»; see also Holl/Pallasmaa/Pérez-Gómez 1994, 36 and Mallgrave 2010, 189: «I would like 
tion is something more than a localized tactile one: ${ }^{23}$ it is a bodily perception, haptein signifies a kind of vision that «grabs» the things it looks at.

Among the elements characterizing Highgate Cemetery as a sepulchral landscape there are many paths (main and secondary ones), which organize the space, the vegetation and the tombs. Highgate Cemetery as a landscape offers itself for a journey experience. One can start from somewhere in the city or from another country, arrive at the cemetery and then go into it. This journey can happen through a series of partial disjunctions (to leave home, to leave the neighbourhood, to leave the main street...) and partial conjunctions (to reach the foot of the hill, to take the climb to the cemetery, to pass the gate, to walk along the paths...) that follow one another. The movement can be performed in different ways: it is possible to go directly to a specific site or to be interested in wandering, having no definite point to reach, one can follow the signals or avoid them for creating one's own path. The pursued goal can be a certain tomb, the Lebanon cedar, but also the sepulchral landscape itself. It is reached thanks to many conditions and through different transformations, by means of separations and unions following and intertwining with one another and giving to the experience of movement a narrative structure. The manner in which one connects places by walking paths is an oriented process marked by a certain rhythm. An «organization of the territory and a syntax of the vision» link space and time and cooperate to shape the experience. ${ }^{24}$ An itinerary is a discursive series of actions, it is spatial practice and narration which describes. But each description has a performative force. ${ }^{25}$ Not only does it reproduce what is visible; it also makes it somehow visible. Each description opens up in a different way the landscape it describes and this makes different openings of the world. ${ }^{26}$ Michel De Certeau discusses two different kinds of description: map-type and tour-type. While the first one refers to the objective relative positions among elements, the second one implies one's body moving through the described places. ${ }^{27}$ Along the path some

to use the term as a synonym for the emotive and multisensory experience of architecture, which includes the visual dimension.»

23 See Gibson 1966.

24 See Fabbri 1998.

25 De Certeau 1988, 123.

26 Another theory distinguishes three types of description: as based on seeing, or based on speaking, or based on doing; see Hammon 1981.

27 De Certeau 1988, 118-122: «The question ultimately concerns the basis of the everyday narrations, the relation between the itinerary (a discursive series of opera- 
transformations can happen. In this way we can say that people live on a landscape.

When Michel Foucault speaks about a cemetery, for example, he names it a heterotopic landscape ${ }^{28}$ describing it as a concrete place, somehow isolated from the rest. This place reproduces the real world but at the same time re-invents it by bringing the subject into an alienating dimension and questioning the usual relationships between the subject and its world. It works also as a heterochrony, problematizing the relationship between the human being and time. On the one hand, a cemetery aims to keep memory alive, tending to a cyclic continuity; on the other, it affirms a discontinuous continuity with the normal time of life characterized by one's own activities which change quickly one after the other, and produces a sort of steadiness. It works by decentralizing one from the usual way of experiencing time and provides an opportunity for a new image of the world.

\section{Highgate Cemetery as a Text}

Many elements of Highgate Cemetery make it possible to experience it as a text with its contents and its forms, main and secondary characters. Like all texts, it has a beginning and an end that need to be identified, but also to be established. Where does Highgate start and finish? Is the street dividing the east side of the cemetery from the west side part of Highgate Cemetery? And what about the road to get there? And the hill on which the graves are located? Such questions about its boundaries also involve questions about its context, and this refers not only to the many relationships with the neighbourhood but also with other Victorian cemeteries.

There is a kind of coherence between all the elements that makes it possible to recognize this place as the one called Highgate Cemetery. This coherence does not arise as fixed and static, but as something dynamic and stratified. It is shaped by the space organization, the use of certain materials and images, the presence of some natural elements, the repetition of certain architectural forms that express and strengthen the social and cultural heritage. Distances and mutual positions of the tombs mark relation-

tions) and the map (a plane projection totalizing observations), that is, between two symbolic and anthropological languages of space», the first is the type cyou turn right and come into the living room (how to enter each room) and organizes movements, the second is the type sthe girl's room is next to the kitchen (the knowledge of an order of places) and is based on seeing.

28 Foucault 1986, 25. 
ships, hierarchies, and suggest orders of importance among the elements composing the place.

This text has some subtexts: this means that one has to recognize many authors and many readers. There are elements that allow the discovery of their enunciator (author) and listener/reader (receiver). ${ }^{29}$ On the one hand, the communicative pact between them depends on the specific kind of text a cemetery is, for it is a place but it is not a hospital or a school. On the other, the pact depends on the specific ways in which the exchanges can happen. They can be, for example, more or less intense from an emotional point of view. In the case of cemeteries, the fact of lasting in time complicates and multiplies these relationships, but many signals give instructions on how to manage the text. It is important to pay attention to different architectural typologies, to titles and epigraphs, to symbolic and decorative elements (fig. 3). ${ }^{30}$ In Highgate there are artefacts with effects designed to convey representational meanings - for example a tomb with a curled-up dog (fig. 4), graves with angels (fig. 5) - and others with a marked constructive function, ${ }^{31}$ for example stairs and narrow passages (fig. 6). Some of these are «mythical buildings». By this, I mean buildings that allow the viewer to go beyond their function and to understand more than what is explicit.

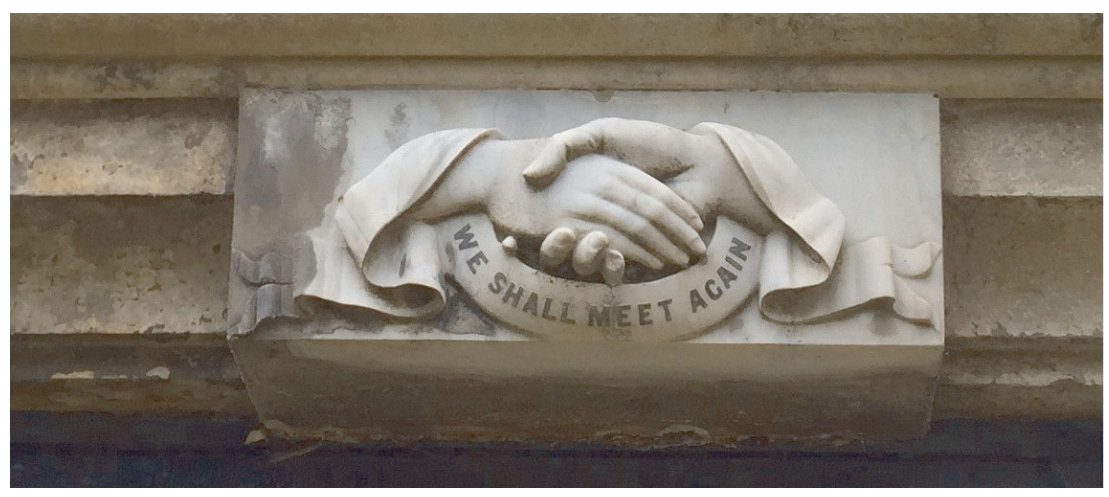

Fig. 3: Symbolic and decorative elements (Image: Carla Danani 2017).

29 See Martin/Ringham 2000, 28, 58, 82, 108.

30 See the contribution of Sean Ryan in this volume.

31 We speak of 1) representational meaning effect when the spatial element brings in itself elements of the external world; 2) constructive meaning effect when what is spoken about is built through and in the spatial element. See Floch 2002. 

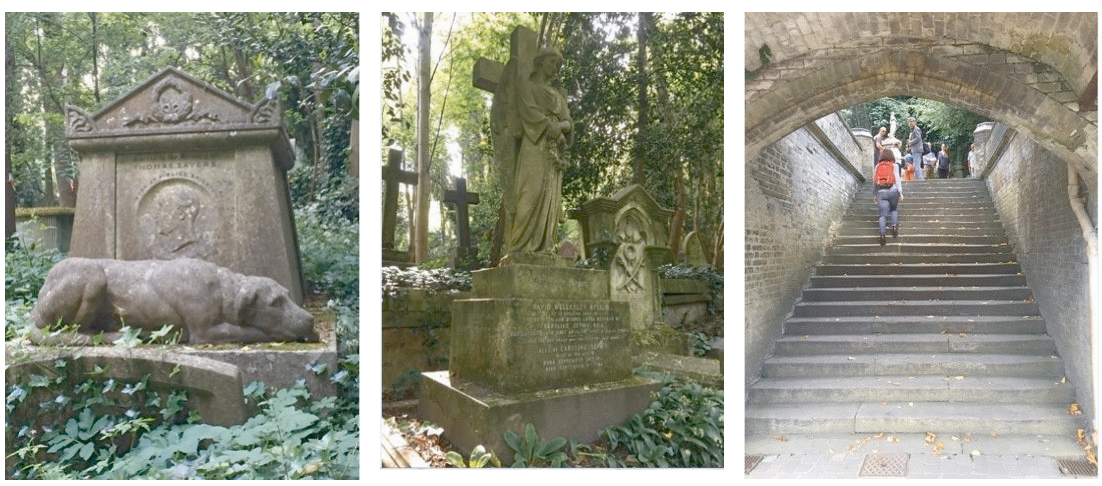

Fig. 4: Grave of Thomas Sayers, with sculpture of his dog, Lion (Image: Carla Danani 2017).

Fig. 5: Angel symbolism (Image: Carla Danani 2017).

Fig. 6: Stairs and passageways (Image: Carla Danani 2017).

Even if every project defines its own ideal user, there is no direct correspondence either between the meaning of a text and the intentions of its authors, nor between the effectivity of a place and the plans of its designers. Furthermore, each configuration follows many refigurations. ${ }^{32}$

One must not believe that specific spatial articulations automatically produce certain effects. Moreover, it is a matter of certain symbolic efficacy of place: there is no relationship of cause and effect but one of significance, that is, a relationship of mutual reference between the level of configuration and the one of meaning. ${ }^{33}$ The symbolic efficacy of a cemetery arises from the relationships between people, spatial configurations, natural and material elements, inscriptions and images. It works and performs at many levels: at a somatic level, through sounds and combinations of materials

32 See Ricoeur 2016, 39: «From now on it is time to talk of inhabiting as a response, even as an answer to building, on the model of the agonistic act of reading, because it will not suffice for an architectural project to be well thought-out, or even for it to be held to be rational for it to be understood and accepted. All planners ought to learn that an abyss can separate the rules of the rationality of a project that is true for all politics, moreover - from the rules of acceptability to a public. We must therefore learn to consider the act of inhabiting as a focus not only of needs, but of expectations. And the same palette of responses as earlier can be travelled, from passive reception, subdued, indifferent reception, to hostile and angry reception - even that of the Eiffel Tower in its day!».

33 See Giannitrapani 2013, 70. 
and odours, which activate the sentient body; at a pragmatic level, through the play of openings and closures, ups and downs, main and secondary paths; at a cognitive level, giving information about dates, parents, social positions, jobs of the deceased, by which a transformation of previous knowledge occurs; at an emotional level, through many elements such as size, light, density and proportions, which bring on affective reactions. A place can also have an «effect of resonance», ${ }^{34}$ when an emotional and pragmatic behaviour is transmitted among many people involving them and producing a unitary feeling.

All relationships happen in time and through many contexts and one cannot have a mechanical rule for understanding them. People constantly rearticulate the places they are in, confirming meanings and values or using tactical behaviour that re-invents new ones. ${ }^{35}$ Practices can give new contents to places, through unexpected uses which sometimes become habits: there may be a time, for instance, when a cemetery somewhere begins to be used as a picnic area.

What a place is, therefore, is not firmly fixed once and for all. ${ }^{36}$ It is a text that undergoes endless refigurations resulting from many practices and their stratifications, diachronic and synchronic intersections of different readers: of many dwellers who live in it and on it, who have to do with it. Sometimes all this leads to a multiplicity of different, maybe conflicting narrations. Lotman suggests one may speak of a polylogue: ${ }^{37}$ where different instances interweave.

\section{Highgate as a Threshold}

People can experience a sepulchral landscape as a threshold, because different spheres have contact and meet or clash in this «third place». ${ }^{38}$ Thresh-

34 See Thom 1968.

35 De Certeau 1988, 38: «Tactics are procedures that gain validity in relation to the pertinence they lend to time-to the circumstances which the precise instant of an intervention transforms into a favourable situation, to the rapidity of the movements that change the organization of a space, to the relations among successive moments in an action, to the possible intersections of durations and heterogeneous rhythms, etc.».

36 See Massey/Jess 1995.

37 See Lotman 1987: A polylogue is more complex than a dialogue, since different discourses, semiotic conflicts and relations weave together, escaping a unique or a bi-unique logic.

38 Agamben 2007, 75: Profanation is a way of eliminating the separation. 
olds may be considered passing devices that modify those who cross them. They work like crossing lines, making it possible to pass from one side to the other. But it is also possible to stand on a threshold, and use it as such. This means that one remains within the tension created by the relationship between what the threshold indicates as something close and what it indicates as something connected while keeping it separate. If someone crosses a threshold, one is no longer on it.

Delimitations avoid confusion and define each part only as a part, as a not-whole. If borders seem to have mostly a demarcating function, as they distinguish the inside from the outside, thresholds show a segmentative function: they introduce articulations. ${ }^{39}$ This means that a threshold not only separates but connects, not only distinguishes but bridges, and points one to consider the many elements in their relationship more than just their consistency. The concepts of continuous and discontinuous, with their associated steps, may be relevant not only to understand the sepulchral landscape in relation to other places, but also its internal configuration, paying attention to the functions of ruptures, connections, crossing passages.

By working as a place where separation and contact occur, a threshold is per se a producer of spatial forms and behaviours. Transition areas are always places of negotiations, where rites, cults and practices, possibilities of exchanges, of transformations, of new semantics occur. These places cannot be considered internal or external, owned or belonging to others. They are intermediary spaces, unstable and open to many possible meanings. Control and practices of power are often introduced, aiming to set up some authority over them.

The binding power of a threshold, which connects by separating and separates by connecting, refers to the spheres it puts in contact. About the sepulchral landscape, one can experience that here almost all life and death, past and present, public and private realms connect. Death and life seem to deny each other, but we cannot really say that one has nothing to do with the other. Death is an unwanted but not an abusive guest in our life. ${ }^{40}$

A cemetery is a town of the dead, who are hosted here in several buildings, tombs and graves. They recall the event of their death, which is often explicitly referred to as premature, painful or heroic. But these buildings also recall their life, with their commitments and traits. The life of the

40 Danani 2017b; the expression is from Alici 2016. 
dead - which has come to an end - is the object of epitaphs, statues and symbols. Moreover, cemeteries are places where people bring the dead, they are obviously built and visited by the living, and tombs are erected to make people remember. This can be understood as a sort of persistence after death. One cannot say that a cemetery is the place of life beyond death: because saying this would mean to believe in a real victory over death, a different form of life that is not experienced here in this world. Instead for those who do not believe in an afterlife, death is nothing more than the end of life.

In cemeteries, that event of no longer having time, that is death, takes spatial shape. However, this happens through the forms built over time by those who still have time. Every cemetery gives human beings this challenge of lingering on a threshold where one may experience the «architectural possibility» of recounting death, the boundary after which no time, no landscape nor architecture exists. Every tomb and every grave appears as keeper of the mystery of death, which cannot be separated from life. In this way Karsten Harries talks about tombs and monuments as boundary markers. ${ }^{41}$

The different architectural styles, the spatial organisations of graves and the monuments tell of people's relation to death, to the dead and to other living beings. Christianity, for example, has interpreted death as defeated by eternal life thanks to the sacrifice of Jesus. The image of the cross indeed celebrates the victory over death by means of death.

Highgate Cemetery appears extremely classical but Romantic, too. It is majestic and many of its tombs are monuments with statues in Greek, Egyptian or Byzantine style: the main part of the West Cemetery develops along an Egyptian Avenue and around the Circle of Lebanon, surrounded by catacombs and having the famous Lebanon cedar at its centre. It is characterized by Classicism and by Gothic style, marked by the tension between finitude and infinity, suggesting a dimension of immortality without avoiding earthly life, but reconciling with it. People walking in Highgate Cemetery perceive a sense of mystery, but nothing is terrible here.

A cemetery is and is not a place of «this life», just as it is and is not a place of death. It works as a threshold between life and death. A cemetery works as a threshold between the public and private sphere, as well. Death marks the existence of human beings all over the world. One can understand the cemetery as a public space also because death concerns all people, making them equal in it: for the dead differences do not count anymore. However,

41 Harries 1998, 299. 
the living continue to experience differences, even if death can transform the perception of them. The cemetery - the landscape housing the dead has always been a common place, a place of the community, with its own legal and moral framework, which falls within social and cultural practices. There can be private tombs, but the cemetery itself - even if reserved for the few and not a site for all the dead - is never a private place. It is an institution for all people, even when it celebrates the epos of a few. Independently of the face-to-face relationships or of the relationships among those bounded by ties, feelings, pacts and laws, everyone deserves to be buried and the sepulchral landscape houses the dead of the past and will house those of the future. The fact of being an institution that potentially concerns and includes everyone (even if treated differently) and the fact that a cemetery houses those who build the community make this place an eminent public space. Through the sepulchral landscape, the public space connects the space of the living, the city and the dead. Robert Jan van Pelt highlights that the necropolis in ancient Athens was located outside the city but just opposite the west gate, the most important one. ${ }^{42}$ This suggests that the necropolis is to be understood as «the moral and pragmatic foundation of the public realm», ${ }^{43}$ because it is not just the place where everyone can remember one's own ancestors but the place of all those who contributed to the existence of the city, which is what one has to take care of, if one wants to take care of oneself. Van Pelt refers to the speech of Pericles and to the death of the heroes in the Peloponnesian War, who died for their homeland. ${ }^{44}$ Moreover, he mentions the epitaph on the column in their honour: they were heroes ready to die, going beyond their interests and therefore triumphing over death.

The sepulchral landscape is a very particular public space: it is a place of silence and immobility, which contrasts with other urban public spaces. If they are usually characterized by outward exteriority and sometimes by formalities, in cemeteries one lives almost always a more intimate experience

42 In the Roman cities the tombs of the famous citizens were clearly visible. With the rise of the Christian city, the tombs were increasingly located in the churches or near them. In 1804 Napoleon decreed that cemeteries be built at a distance of at least 35/40 metres from the city's borders, and a similar law was decided in the British islands around 50 years later. The new European cemeteries owe their existence to a secular initiative rather than to a religious one and they were under municipal jurisdiction rather than under the local clerical one.

43 Van Pelt 1991, 193.

44 Van Pelt 1991, 187. 
within oneself and towards other people. ${ }^{45}$ The sepulchral landscape is characterized by an atmosphere of "common" ground and of shared humanity, as well as by a mood of interrupted very personal connections. ${ }^{46} \mathrm{In}$ the public space everyone is «the third» for all the others, in a sort of fundamentally egalitarian isonomy, because public space is the place that connects people going beyond the face to face encounter, here everyone can express himself or herself as equal to others. However, death is a really personal, intimate experience. At any given moment someone dies on the earth, but the death of a beloved person suspends everything and is the loss of a world. This day marks a turning point, and life will never be the same as before. Giving itself as public landscape and also as private place, the cemetery performs as a threshold: where the tension between different spheres relates and settles.

The cemetery also involves a time dimension, where past and present connect. The gravestones recount universal continuity: they bring the past into the present to make it last, meaning memorialization and giving existence to what is no longer living.

These places are powerful imagination shifters, in which people find suggestions to remember the life of the dead, to travel in biographies, to go beyond one's own finitude. This performance as a threshold between past and present works in many ways. It has a factual ground: for example, due to the fact that people of a certain era are buried there and that their tombs have a particular architectural style, they are still visited and renewed or are in ruins. It has a cultural iconographic dimension, linked also to some rituals: for example some tombs have a monument in the shape of an angel $^{47}$ or a broken column, others have crosses symbolizing religious beliefs, flowers ${ }^{48}$ or votive lights suggesting that life is somehow continuing. It has an affective and pathos dimension: the statue of a suffering dog on a tomb creates empathy towards a loss, a farewell poem inspires nostalgia for what

45 See Thiolliere 2014.

46 About atmosphere see Böhme 2006 and Pallasmaa 2014. I distinguish atmosphere from mood, because one can say that there is a funny atmosphere (which is very different from a mourning one), but that he/she is in a bad mood (which is different from a good one). The atmospheric perception is a holistic and emotional being-in-the world in which the pole of the world prevails; the mood is an emotional being-in-the world highlighting the pole of the embodied consciousness. Atmosphere is the way of being of a place considered in its relationship with the feelings and reactions of the people, mood is the way of being of a human being, considered in his/her relationship with place.

47 See the contribution of Fritz in this volume.

48 See the contributions of Ryan and Wyss-Giacosa in this volume. 
now can no longer be or has been lost. ${ }^{49}$ It has a social-political dimension: a tomb can exhibit the tools of a specific job and celebrate over time its social relevance, another sepulchre is very big, fenced in and located at the point where the main path splits, honouring permanently an important public role.

\section{Place as Event}

As laid out in this hermeneutic-phenomenological research I understand Highgate Cemetery as a place, which happens as a sepulchral landscape, as a text, as a threshold between life and death, present and past, private and public sphere. The location, forms, proportions and structure of the graves express power relations, social and cultural meanings that today perhaps have, or perhaps no longer have, current legitimations.

The media for this performance of the elements of the sepulchral place are imagination and memory, which enable its symbolic efficacy through significant relationships. Writings, pictures, decorations, statues, forms and frames are some elements where memory works, laboratories where memory is called and experienced, where it intertwines with remembering and gives itself to the present. ${ }^{50}$ Highgate Cemetery can be experienced as a landscape, a text and a threshold by means of its many elements and its frame, and one can highlight the threshold performance working through landscape and textual features. This place happens as a transformation offer: because a threshold is a point for discontinuity and a tool for novelties; it exists as a «trans-passing» function. Highgate Cemetery happens as a possibility to understand the form of the environment, for reading a meaning, for experiencing a condition of liminality outside of the usual everyday routine.

\section{Bibliography}

Alici, Luigi, 2016, Il fragile e il prezioso. Bioetica in punta di piedi, Brescia: Morcelliana.

Agamben, Giorgio, 2007, In Praise of Profanations, in: Agamben, Giorgio, Profanations, trans. Jeff Fort, New York: Zone Books, 73-92.

49 See the contribution of Ornella in this volume.

50 See Nora 1984, 8. 
Assunto, Rosario, 1976, Paesaggio-Ambiente-Territorio. Un tentativo di precisazione concettuale, in: Bollettino del Centro Internazionale di Studi di Architettura Andrea Palladio, XVIII, 45-48.

Böhme, Gernot, 2006, Architektur und Atmosphäre, München: Fink.

Casey, Erwin, 1996, How to Get from Space to Place in a fairly Short Stretch of Time, Phenomenological Prolegomena, in Senses of Place, in: Feld, Steven/ Basso, Keith H., Senses of Place, Santa Fe: School of American Research Press, 13-52.

Chandler, Alice, 1971, A Dream of Order: The Medieval Ideal in Nineteenth-Century English Literature, Lincoln: University of Nebraska Press.

Danani, Carla, 2018, «Oikosophia». Prospettive filosofiche dell'abitare, in: Boselli, Goffredo (ed.), Abitare Celebrare Trasformare. Processi partecipativi tra liturgia e architettura, Magnano: Qiqaion, 79-104.

Danani, Carla, 2017a, Religion und Öffentlichkeit. Wie ein Raum sich bildet in Die Irritation der Religion. Zum Spannungsverhältnis von Philosophie und Theologie, in: Danani, Carla/Perone, Ugo/Richter, Silvia, Die Irritation der Religion, Göttingen: Vandenhoeck \& Ruprecht, 147-169.

Danani, Carla, 2017a, La morte dentro la vita, ospite indesiderato ma non abusivo, Rivista per le Medical Humanities 37, 105-111.

Danani, Carla, 2014, Human Dwelling: A Philosophical Question Concerning Place and Space, in: Pezzoli-Olgiati, Daria/George, Mark, Religious Representation in Place. Exploring Meaningful Spaces at the Intersection of the Humanities and Sciences, New York: Palgrave Macmillan Press, 47-60.

De Certeau, Michel, 1988, The Practice of Everyday Life, trans. Timothy J. Timosik, Berkeley: University of California Press.

Deleuze, Gilles, 1986, Le cerveau, c'est l'écran, entretien avec Gilles Deleuze, Cahiers du cinema 380, février, 24-36.

Deleuze, Gilles/Guattari, Félix, 1987, A Thousand Plateaus. Capitalism and Schizophrenia, trans. Brian Massumi, Minneapolis: University of Minnesota Press.

Di Molfetta, Felice, 2006, Inumazione e cremazione. Tradizione cristiana, ritualità, legislazione, Rivista Liturgica - Bimestrale per la formazione liturgica, 5, sett.ott., 739-755.

Eco, Umberto, 2000, Kant and the Platypus. Essays on Language and Cognition, New York: Mariner Books (orig. 1997, Kant e l'ornitorinco, Milano: Bompiani).

Eco, Umberto, 1990, The Limits of Interpretation, Bloomington/Indianapolis: Indiana University Press (orig. 1990, I limiti dell'interpretazione, Milano: Bompiani).

European Landscape Convention, 2000, https:/www.coe.int/en/web/landscape (accessed April 28, 2018).

Fabbri, Paolo, 1998, La svolta semiotica, Roma-Bari: Laterza.

Ferrari, Federico (ed.), 2007, Del Contemporaneo. Saggi su arte e tempo, Milano: Mondadori. 
Floch, Jean-Marie, 2002 (1990), Sémiotique, marketing et communication. Sous les signes, les stratégies, Paris: PUF, $3^{\text {rd }}$ ed.

Foucault, Michel, 1986, Of Other Spaces, trans. Jay Miskowiec, Diacritics 16/1, 2227.

Giannitrapani, Alice, 2013, Introduzione alla semiotica dello spazio, Roma: Carocci.

Gibson, James J., 1966, The Senses Considered as Perceptual Systems, Oxford: Houghton Mifflin.

Hammon, Philippe, 1981, Introduction à l'analyse du descriptif, Paris: Hachette.

Harries, Karsten, 1998, The ethical Function of Architecture, Cambridge (Mass.): MIT Press.

Heidegger, Martin, 2002, On Time and Being, trans. Joan Stambaugh, Chicago: University of Chicago Press, 1-24 (orig. 1969, Zeit und Sein, in: Heidegger, Martin, Zur Sache des Denkens, Tübingen: Niemeyer, 1-25).

Holl, Steven/Pallasmaa, Juhani/Pérez-Gómez, Alberto (eds.), 1994, Questions of Perception: Phenomenology of Architecture, Tokyo: A+U.

Husserl, Edmund, 2001, Analyses concerning passive and active Synthesis: Lectures on transcendental Logic, trans. Anthony J. Steinbock, Dordrecht (NL): Kluwer Academic Publishers, orig. 1966, Analysen zur passiven Synthesis. Aus Vorlesungs- und Forschungsmanuskripten, 1918-1926, Husserliana 11, The Hague: Martinus Nijhoff.

Husserl, Edmund, 1994, Die Krisis der europäischen Wissenschaften und die transzendentale Phänomenologie. Ergänzungsband. Texte aus dem Nachlass 19341937, Husserliana, Bd. XXIX, Dordrecht: Kluwer Academic Publisher.

Lorca, F. García, 1993, Impressioni e paesaggi, edited by Carlo Bo, Firenze: Passigli.

Lotman, Yuri, 1987, Architecture in the Context of Culture, Architecture and Society (Архитектура и общество), 6, 8-15 (Parallel text in Russian).

Mallgrave, Harry Francis, 2010, The Architect's Brain: Neuroscience, Creativity, and Architecture, Chichester: Wiley-Blackwell.

Martin, Bronwen/Ringham, Felizitas, 2000, Dictionary of Semiotics, London/New York: Cassell.

Massey, Doreen/Jess, Pat (eds.), 1995, A Place in the World? Places, Culture and Globalisation, Oxford: Oxford University Press.

Merleau-Ponty, Maurice, 1962, Phenomenology of Perception, trans. Colin Smith, London/New York: Routledge \& Kegan Paul.

Nora, Pierre, 1984, Les lieux de mémoire, La République, Paris: Gallimard.

Pallasmaa, Juhani, 1994, An Architecture of the Seven Senses, in: Holl, Steven/ Pallasmaa, Juhani/Pérez-Gómez, Alberto, 1994, Questions of Perception: Phenomenology of Architecture, special issue of $\mathrm{A}+\mathrm{U}$, Architecture and Urbanism, Tokyo: A+U, 27-37. 
Pallasmaa, Juhani, 2014, Space, Place and Atmosphere. Emotion and Peripheral Perception In Architectural Experience, Lebenswelt, 4, 230-245, https:// riviste.unimi.it/index.php/Lebenswelt/article/view/4202/4292 (accessed June 28, 2018).

Parker Pearson, Michael, 1999, The Archaeology of Death and Burial, College Station: Texas A\&M University Press.

Piana, Giovanni, 2016 (1992), Phenomenology as Philosophical Method, Metodo. International Studies in Phenomenology and Philosophy, 4/1, 184-204, http:// www.filosofia.unimi.it/piana/ (accessed April 28, 2018).

Ricoeur, Paul, 2016, Architecture and Narrativity, trans. Eileen Brennan, Robbie Carney and Samuel Lelièvre, Études Ricoeuriennes/Ricoeur Studies 7/2, , 31-42.

Schlögel, Karl, 2003, Im Raume lesen wir die Zeit. Über Zivilisationsgeschichte und Geopolitik, München: Carl Hanser Verlag.

Thiollière, Pascaline, 2014, The Cemetery as Figure of Intimate Public Space, at: International Architecture Philosophy Conference. Autonomy Reconsidered: Ethics in Architecture, Urbanism and Landscape, Delft (NL): July 2014.

Thom, René, 1968, Topologie et signification, in Thom, René, L'âge de la science, 4, 1-24.

Van Pelt, Robert Jan, 1991, Athenian Assurance, in: van Pelt, Robert Jan/Westfall, Carroll William, Architectural Principles in the Age of Historicism, New Haven: Yale University Press, 168-261.

Venturi Ferriolo, Massimo, 2003, Etiche del paesaggio, Roma: Editori Riuniti.

Zilberberg, Claude, 1993, Seuils, limites, valeurs, in: Tarasti, Eero (ed.), On the Borderlines of Semiotics, Acta Semiotica Fennica II, Imatra: Oylä-Vuoksi, 379395. 